\title{
Pre-Service Teachers' Teaching Anxiety about Mathematics and Their Learning Styles
}

\author{
Murat Peker \\ Afyon Kocatepe Universitesi, Afyonkarahisar, TURKIYE
}

Received 17 May 2008; accepted 12 February 2009

The purpose of this study was to investigate the differences in the teaching anxiety of preservice teachers in mathematics according to their learning style preferences. There were a total of 506 pre-service teachers involved in this study. Of the total, 205 were pre-service elementary school teachers, 173 were pre-service elementary mathematics teachers, and 128 were pre-service secondary mathematics teachers. In the collection of the data, the researcher employed two types of instruments: the Learning Style Inventory (LSI) and the Mathematics Teaching Anxiety Scale (MATAS). The LSI determined the participants' learning style preference: divergent, assimilator, convergent, and accommodator. The MATAS found the participants' mathematics teaching anxiety level. The researcher used the one-way ANOVA with $\alpha=0.05$ in the analysis of the data. The study revealed that there were statistically significant differences in mathematics teaching anxiety between convergent and the other three types of learners: divergent, accommodator, and assimilator. The difference was in favour of convergent learners. In other words, convergent learners had less mathematics teaching anxiety than the other types of learners. The study also found that divergent learners showed the highest level of mathematics teaching anxiety.

Key words: Teaching anxiety, mathematics education, pre-service teacher, learning styles.

\section{INTRODUCTION}

Research has demonstrated that many students have learning difficulties and show poor performance in mathematics (Halat, 2006/2007). There are many variables, such as mathematics anxiety (Baloğlu, 1999/2001), learning styles (Sloan, Daane, \& Giesen, 2002; Peker, 2005), instruction (Vinson, 2001; Iossi, 2007), lack of self-confidence (Uusimaki \& Nason, 2004; Brady \& Bowd, 2005), teacher beliefs, environment (Uusimaki \& Nason, 2004), lack of parental support (Engelhard, 1990; Uusimaki \& Nason 2004), and gender (Altermatt \& Kim, 2004), that appeared to affect students' mathematics learning abilities. It seems that mathematics anxiety is an

Correspondence to: Murat Peker, PhD in Mathematics Education, Afyon Kocatepe Universitesi, Egitim Fakultesi, 03100, Afyonkarabisar, TURKEY

E-mail:peker@aku.edu.tr important factor that affects student achievement and attitude towards mathematics (Hembree, 1990). Baloğlu (1999/2001) stated that mathematics anxiety is the most crucial problem in learning and teaching mathematics. Therefore, many research studies have been conducted on this issue in the last two decades (Wigfield \& Meece, 1988; Aksu \& Saygi, 1988; Beasley, Long \& Natali, 2001; Baloğlu, 2001/2005). According to Engelhard (1990), these studies will apparently go on unless the students get rid of their anxiety.

\section{Mathematics Anxiety and Mathematics Teaching Anxiety}

Today, mathematics anxiety is an important and common phenomenon in students from elementary through university levels. In order to understand mathematics anxiety, one should initially learn the complexity of this concept (Uusimaki \& Nason, 2004). Richardson and Suinn defined mathematics anxiety as 
"feelings of tension and anxiety that interfere with the manipulation of numbers and the solving of mathematical problems in a wide variety of ordinary life and academic situations" (cited in Newstead, 1998, p.54). According to Trujillo and Hadfield (1999), the causes of mathematics anxiety can be classified in three categories: personality factors, environmental factors, and intellectual factors. The personality factors include reluctance to ask questions due to shyness, low selfesteem, and, for females, viewing mathematics as a male domain. Environmental factors include negative experiences in the classroom, parental demands, insensitive teachers, and use of the traditional teaching method, where mathematics is taught and thought of as the memorization of formulas, and the long and monotonous computation and manipulation of numbers (Idris, 2006). Intellectual factors include being taught with mismatched learning styles, student attitude and lack of persistence, lack of confidence in mathematical ability, and the lack of perceived usefulness of mathematics. According to Cassady and Johnson (2002), high levels of emotionality are considered to be benign in exams when the individual maintains a high level of self-confidence regarding performance.

The research documented that there have been many studies done on pre- or in-service teachers' mathematics anxiety (Austin, Wadlington \& Bitner, 1992; Vinson, Haynes, Brasher, Sloan \& Gresham, 1997; Sloan, Vinson, Haynes \& Gresham, 1997; Tooke \& Lindstrom, 1998; Newstead, 1998; Brown, McNamara, Hanley \& Jones, 1999; Vinson, 2001; Uusimaki \& Nason, 2004; Brady \& Bowd, 2005; Idris, 2006; Gresham, 2007). For example, according to Brown et al. (1999), Uusimaki and Nason (2004), and Malinsky, Ross, Pannells, and McJunkin (2006), the origin of pre-service teachers' negative beliefs and anxiety about mathematics could be attributable to prior school experiences, such as experiences as a mathematics student, and the effect of prior teachers, and of teacher training programs. Uusimaki and Nason (2004) stated that pre-service primary school teachers' negative experience and anxiety about mathematics were attributed to their teacher rather than to other factors, such as mathematical concepts, parents, or peers. They also claimed that "Situations which caused most anxiety for the participants included communicating one's mathematical knowledge, whether in a test situation or in the teaching of mathematics such as that required on practicum" (p. 374). According to Trujillo and Hadfield (1999), there were many similarities among the experiences of the pre-service elementary teachers, such as negative school experiences, lack of family support, and general test anxiety. They stated that all of the preservice teachers suffered from severe mathematics anxiety, but that despite these disadvantages, all of the participants planned to employ the constructivist and developmental methods they learned in their college mathematics methods classes in order to make mathematics meaningful to their own students.

Anxiety concerning teaching mathematics is a frequent fear of pre-service teachers. It may reflect real or perceived knowledge deficits in mathematics content as well as in mathematics teaching skills, and memories of past occurrences of mathematics failure or anxiety (Levine, 1993). Gardner and Leak (1994) conceptualized teaching anxiety as anxiety experienced in relation to teaching activities that involve the preparation and execution of classroom activities. Teaching anxiety in general appears to be a problem for a significant number of post-secondary educators (Gardner \& Leak, 1994; Ameen, Guffey, \& Jackson, 2002). And mathematics teaching anxiety appears to be a specific problem. Mathematics teaching anxiety can be defined as pre- and in-service teachers' feelings of tension and anxiety that occurs during teaching mathematical concepts, theories, and formulas or during problem solving (Levine, 1993; Peker, 2006). The symptoms of mathematics teaching anxiety can include extreme nervousness, the inability to concentrate, negative selftalk, being easily upset by noises, being unable to hear the students, and sweaty palms - to name just a few. Godbey (1997) stated that negative self-talk can be the root cause of mathematics failure in some students. In fact, negative self-talk can be the root cause of mathematics teaching anxiety in some pre-service teachers, too. When teaching a mathematical concept in practice, the pre-service teacher probably will not be able to teach a mathematical concept if she or he is constantly saying to themselves, I can't teach this concept, or I have never been good at mathematics teaching, or I just can't teach this problem solving. The teacher can fail simply because they're convinced they cannot be successful in teaching.

The research has shown that there were many studies done on the mathematics teaching anxiety with the pre-service teachers (Levine, 1993/1996; Peker, 2006/2008, Peker \& Halat, 2008). For instance, Levine (1993) examined the anxiety about teaching mathematics among pre-service elementary school teachers. He stated that there was a significant decrease in anxiety in teaching mathematics from the initial to the final meeting of the mathematics methods course during which instructional practices consistent with recommendations of the NCTM (National Council of Teachers of Mathematics) in the United States (1989) were introduced. According to Levine (1996), abstract discussions regarding mathematical concepts increased the teaching anxiety of the pre-service elementary teachers who had high level of anxiety for teaching mathematics, but using manipulative materials, getting familiar with developing creative teaching strategies for 


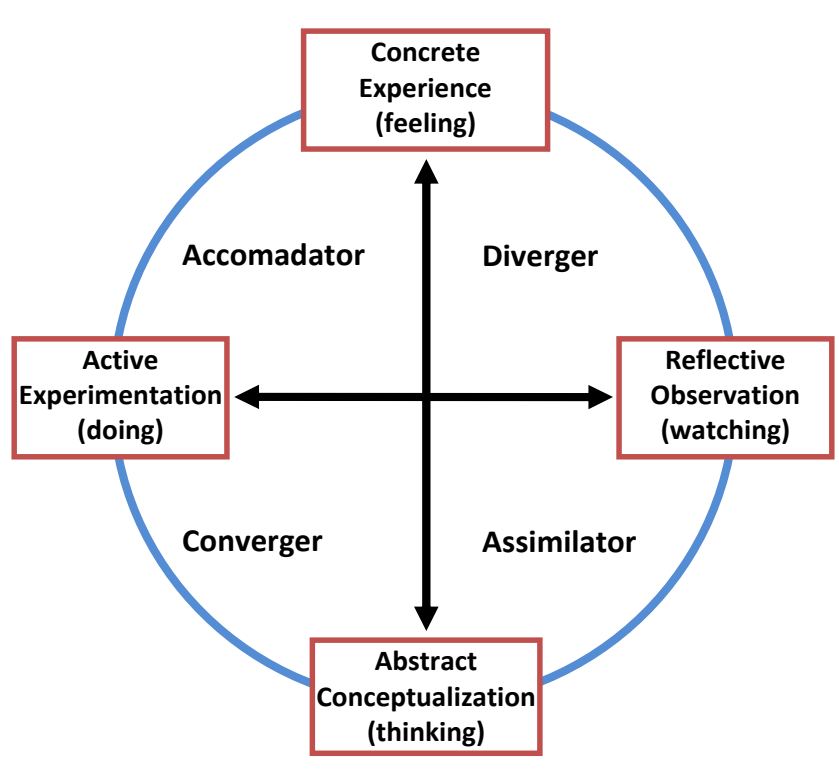

Figure 1. Elements of Kolb's Learning Styles

(Kolb, 1984).

teaching mathematics and learning to design lesson plans in mathematical concepts reduced the teaching anxiety level of these teachers. Furthermore, Peker (2006) stated that there were several factors, such as content knowledge, attitude towards mathematics, and self confidence related to both mathematics anxiety and mathematics teaching anxiety. Ameen, Guffey, and Jackson (2002) reported that accounting educators' intensity of teaching anxiety was affected by teaching experience, age and rank. Although Ameen et al. claimed that the factors not affecting the intensity of the teaching anxiety were gender and ethnicity, in another study, Fish and Fraser (2001) found that among the university professors surveyed about teaching anxiety, gender was a factor, with female faculty reporting more teaching anxiety than males. Furthermore, Peker and Halat (2008) found that gender was not a factor among the pre-service elementary school teachers' mathematics teaching anxiety. Since little research has been done in the area of mathematics teaching anxiety among preservice teachers regarding learning styles, this research was undertaken to contribute to this area.

\section{Learning Styles}

Every person has a learning style preference. Knowing students' learning style preferences, teachers and educators can organize classrooms to respond to the students' individual needs for, for instance, total quiet or background sound, bright or soft illumination, warm or cool room temperatures, seating arrangements, mobility, or grouping preferences (Dunn, Beaudry, \& Klavas, 1989). According to Kolb (1984), learning styles are complex and not easily reducible into simple typologies. He stated that "the way we process the possibilities of each new emerging event which determines the range of choices and decisions we see, and the choices and decisions we make, for some events to determine the events we live through which influence our future choices" (p. 64). To assess individual orientations toward learning, the Learning Style Inventory (LSI) was created and revised by Kolb (1976/1985).

Kolb (1984) claimed that if learners (pre-service teachers) are to be effective they need ability in four different areas: concrete experience (CE), reflective observation (RO), abstract conceptualization (AC), and active experimentation (AE). That is, they must be able to involve themselves fully, openly, and without prejudice in new experiences for a concrete experience. They must be able to reflect on and view these experiences from many perspectives for reflective observation. They must be able to create concepts that integrate their observations into logically sound theories for abstract conceptualization. And they must be able to use these theories to make decisions and solve problems for active experimentation. In this model, learning style is determined by where the person's preference of perceiving information is on a scale from the concrete to the abstract (defined as feeling-thinking), and whether the person's preference of processing information is closer to active experimentation or reflective observation (defined as doing-watching). These preferences result in a classification of the person's learning style. But the person may have discovered that no single mode entirely describes his or her learning style. This is because the learning style of most students is a combination of all four styles (Kolb, 1984/1985). Kolb identified four different learner types as follows: divergent learners, assimilator learners, convergent learners, and accommodator learners [See figure 1].

According to Kolb, (1984/1985), and Baker, Dixon, and Kolb (1985), the followings are the characteristics and strengths of the four learning style types.

Divergent learners learn by combining concrete experience with reflective observation. They are best at viewing concrete situations from many different points of view. Assimilator learners learn by combining abstract conceptualization with reflective observation. They are best at understanding a wide range of information and putting it into concise logical form. They are interested in abstract ideas and concepts, planning, creating models, defining problems, developing theories, and learning from detailed explanations. They are usually most effective in information and sciences careers. Convergent learners learn by combining abstract conceptualization with active experimentation. They take abstract ideas and actively experiment to find practical uses for the information by finding solutions to 
problems. They are best at finding practical uses for ideas and theories, dealing with technical tasks and problems, problem solving, decision making, deductive reasoning, defining problems, and learning by developing individual strategies. Their effectiveness is often best in specialist and technology careers. Accommodator learners learn by combining concrete experience with active experimentation. They mix concrete experiences with active experimentation. They are best at learning from hands-on experience, carrying out plans, getting things done, leadership, risk taking, and learning by trial and error. They are often most effective in action-oriented careers such as marketing or sales.

Perceiving and processing knowledge is crucially important in learning and teaching mathematics. According to Kolb (1984), learning styles are specified using two dimensions: perceiving knowledge and processing knowledge. According to Knisley (2002), the learning model most applicable to learning mathematics is Kolb's model of experiential learning. Therefore, Kolb's Learning Style Inventory was taken into consideration as the learning style for this study.

Research results appear varied as to whether learning styles and mathematics achievement are significantly related (Gasiorowski, 1998). For instance, Hadfield and Maddux (1988) found no statistically significant differences between mathematics achievement and learning styles. On the other hand, according to several other research findings, learning style preference is an important factor in student achievement and attitudes towards mathematics (Smith, 1996; Peker, 2005; Peker \& Mirasyedioğlu, 2008). For example, Peker (2005) found that learning style was a good predictor of mathematics achievement for pre-service teachers. Peker and Mirasyedioğlu (2008) found significant differences in attitudes towards mathematics among pre-service elementary school teachers with different learning styles. Besides, Hadfield and Maddux (1988), Hadfield, Martin, and Wooden (1992), and Sloan, Daane, and Giesen (2002) claimed that learning styles were related to mathematics anxiety. For example, Hadfield and Maddux (1988) found that field-dependent learners experienced more mathematics anxiety than did field-independent learners. Sloan, Daane, and Giesen (2002) reported that there was a relationship between mathematics anxiety and global learning style. They determined that a higher level of global learning was related to higher levels of mathematics anxiety. However, there were no studies done on mathematics teaching anxieties related to learning styles with preservice teachers. Since no research has been done on mathematics teaching anxiety related to learning styles among pre-service teachers, this research was undertaken to contribute to this area.
The current study was designed to find out the learning styles of pre-service teachers-specifically, preservice elementary school teachers, and pre-service elementary and secondary mathematics teachers- and to investigate mathematics teaching anxiety among these groups. Specifically, the research project seeks to:

\section{(1) determine the pre-service teachers' learning style preference;}

(2) determine if there is any significant change in mathematics teaching anxiety among pre-service teachers; and

(3) determine if there is any significant change in mathematics teaching anxiety among pre-service teachers based on their learning styles.

Specifically, it will seek to find answers to the following questions:

(1) What types of learning styles do pre-service elementary school teachers, and pre-service elementary and secondary mathematics teachers have?

(2) What differences, if any, exist in mathematics teaching anxiety among pre-service elementary school teachers, and preservice elementary and secondary mathematics teachers?

(3) What differences, if any, exist in mathematics teaching anxiety among pre-service elementary school teachers, and preservice elementary and secondary mathematics teachers based on their learning styles?

\section{METHOD}

\section{Participants}

This study included 506 pre-service teachers. There were a total of $205(40.5 \%)$ pre-service elementary school teachers, $173(34.2 \%)$ pre-service elementary mathematics teachers and $128(25.3 \%)$ pre-service secondary mathematics teachers enrolled in teacher education programs in three different universities in Turkey. About $57 \%$ of participants were male (286) and $43 \%$ were female (220) in the study. The mean age of participants was 22.41 years $(\mathrm{SD}=1.681)$.

\section{Instruments}

The researcher used two instruments in the collection of the data: the Learning Style Inventory (LSI) and the Mathematics Teaching Anxiety Scale (MATAS).

\section{Learning Style Inventory}

Pre-service teachers' learning style preferences were determined using the Learning Style Inventory (LSI) developed and revised by Kolb (1976/1985). A research of LSI was done towards its applicability in Turkish by Askar \& Akkoyunlu (1993). The LSI describes the ways 
people learn and how people deal with ideas and day-today situations in their life. It has been a very useful tool in understanding our students' learning style preferences in the learning process (Kolb, 1985). According to Kolb (1984/1985), learning is a four-stage process involving concrete experience (CE), reflective observation (RO), abstract conceptualization (AC), and active experimentation (AE). In Kolb's model, learning style is determined according to where the person's preference of perceiving information ranges on a scale from the concrete to the abstract, and whether the person's preference for processing information is closer to active experimentation or to reflective observation. These preferences result in a classification scheme of the person's learning style.

The LSI consists of twelve incomplete statements that help respondents attempt to describe their learning style. Each item of the questionnaire asks respondents to rank their order of four sentences that correspond to the four learning modes-concrete experience, reflective observation, abstract conceptualization, and active experimentation (Kolb, 1985). Examples of LSI statements are given below.

First statement:

When I learn

- I like to deal with my feelings (CE)

- I like to watch and listen (RO)

- I like to think about ideas (AC)

- I like to be doing things (AE)

Twelfth statement:

I learn best when

- I am receptive and open minded (CE)

- I am careful (RO)

- I analyse ideas (AC)

- I am practical (AE)

Pre-service teachers in the study were asked to rank the completion phrases from 1 to 4 according to how they felt personally when they were applied to them. A ranking of "1" was used for the completion phrase that was least like the way learned; a ranking of " 4 " was used for the completion phrase that was most like the way learned. Results indicated the four learning stages of the pre-service teachers: $\mathrm{CE}, \mathrm{RO}, \mathrm{AC}$, and AE. A total score for each of the four learning stages was then summed over the twelve items. The AE-RO and ACCE differences were computed. In this way, the results identified the learning style of these pre-service teachers.

\section{Mathematics Teaching Anxiety Scale}

The researcher also used the Mathematics Teaching Anxiety Scale (MATAS) in the study. It was developed by the Peker (2006) to determine the pre-service teachers' mathematics teaching anxiety levels and scores.
The MATAS is a liker-type questionnaire including 23 items. The participants were asked to rate the statements on a five-point scale: completely agree, agree, undecided, disagree, or completely disagree. The negative statements were weighted from 5 to 1 , and positive statements were reversed. Therefore, the sum of the scores on the questionnaire showed the mathematics teaching anxiety level of the pre-service teachers.

Factor analyses revealed four factors. These are as follows: Content knowledge - 10 items (factor loading ranging from 0.53 to 0.86 ), Self-confidence -6 items (factor loading ranging from 0.57 to 0.76 ), Attitude towards mathematics teaching -4 items (factor loading ranging from 0.61 to 0.70 ), and Teaching knowledge -3 items (factor loading ranging from 0.68 to 0.78 ). Reliability estimates of the MATAS were obtained by using Cronbach's alpha measure for each subscale. They were "Content knowledge": 0.90, "Self-confidence": 0.83, "Attitude towards mathematics teaching": 0.71, "Teaching knowledge": 0.61, Total Scale: 0.91. Some examples of the items in the scale are as follows:

"I got anxious when it comes to the point of teaching some mathematical topics" is an example of content knowledge.

"It is very easy for me to teach mathematics" is an example of self-confidence.

"I like answering questions about the topic I am teaching" is an example of attitude towards mathematics teaching.

"Throughout my career as a teacher, I think I can make use of the different views and theories about teaching mathematics" is an example of teaching knowledge.

\section{Procedure and Data Analysis}

There was no time limitation for the testing session, however most pre-service teachers finished the MATAS within 15 minutes, and the LSI also within 15 minutes. The maximum possible score on the MATAS a person can make is 115 ( $23 \times 5)$, and the minimum score is 23 $(23 \times 1)$. In the determination of the anxiety level the researcher used the total points taken from the MATAS. The researcher employed the one-way ANOVA with $\alpha$ $=0.05$ in the analysis of the differences of pre-service teachers' teaching anxieties in mathematics based on their learning styles.

\section{RESULTS}

\section{Pre-service Teachers' Learning Styles}

Question 1: What types of learning styles do pre-service elementary school teachers, and pre-service elementary and secondary mathematics teachers have? 
Table 1 shows descriptive statistics for the preservice teachers' learning style preference. It shows that the participants in the study had all four learning styles in different percentages. The convergent learners had the highest percentage (43.7\%) of the learner groups. About ten percent of the participants were determined to be primarily divergent learners. That percentage was the lowest of the four groups.

Table 2 shows the distributions of the learning styles of pre-service elementary school teachers, and preservice elementary and secondary mathematics teachers in teacher training programs. The learning styles of preservice elementary school teachers were in the following order: convergent learners, 37.6\%; assimilator learners, $33.7 \%$; accommodator learners, $16.6 \%$; and divergent learners, $12.2 \%$. Pre-service elementary mathematics teachers' learning styles were as follows: convergent learners, $49.7 \%$; assimilator learners, $26.6 \%$; accommodator learners, $14.5 \%$; and divergent learners, $9.2 \%$. The learning styles of pre-service secondary mathematics teachers were in the following order: convergent learners, 45.3\%; assimilator learners, 37.5\%; accommodator learners, $9.4 \%$; and divergent learners, $7.8 \%$.

Interestingly, in general and in each group, the order of the learning styles of the participants was the same: most were convergent learners, followed by assimilator learners, then accommodator learners, and finally divergent learners. Both convergent and assimilator learners in general and in all three groups were about $70 \%$ or more of the participants. Moreover, the percentage of the convergent learners from pre-service elementary school teachers to pre-service secondary mathematics teachers increased. It was the opposite for the divergent learners in the study.

\section{Pre-service Teachers' Mathematics Teaching Anxiety}

Question 2: What differences, if any, exist in mathematics teaching anxiety among the pre-service elementary school teachers, and pre-service elementary and secondary mathematics teachers?

Table 3 shows descriptive statistics for the preservice teachers' mathematics teaching anxiety. It indicates that the mean score of the pre-service secondary mathematics teachers' teaching anxiety in mathematics was the lowest, and that the mean score of the pre-service elementary school teachers' mathematics teaching anxiety was the highest. Pre-service elementary school teachers present topics to students who are in the concrete operational stage of Piaget's cognitive developmental stages. It is thought that pre-service elementary teachers attach more importance to concrete learning since they are usually educated in college this way. Moreover, it is evident that pre-service elementary school teachers stress concrete learning more than preservice secondary teachers.

Table 1. Descriptive Statistics for the Pre-service Teachers' Learning Styles in General

\begin{tabular}{lll}
\hline & $\mathrm{n}$ & $\%$ \\
\hline Divergent Learners & 51 & 10.1 \\
Assimilator Learners & 163 & 32.2 \\
Convergent Learners & 221 & 43.7 \\
Accommodator Learners & 71 & 14.0 \\
Total & 506 & 100 \\
\hline
\end{tabular}

Table 2. Descriptive Statistics for the Pre-service Teachers' Learning Styles based on a Specific Programs

\begin{tabular}{lllllll}
\hline & \multicolumn{2}{l}{$\begin{array}{l}\text { Pre-service Elementary } \\
\text { School Teachers }\end{array}$} & \multicolumn{2}{l}{$\begin{array}{l}\text { Pre-service Elementary } \\
\text { Mathematics Teachers }\end{array}$} & \multicolumn{2}{l}{$\begin{array}{l}\text { Pre-service Secondary } \\
\text { Mathematics Teachers }\end{array}$} \\
\hline & $\mathrm{n}$ & $\%$ & $\mathrm{n}$ & $\%$ & $\mathrm{n}$ & $\%$ \\
\hline Divergent Learners & 25 & 12.2 & 16 & 9.2 & 10 & 7.8 \\
Assimilator Learners & 69 & 33.7 & 46 & 26.6 & 48 & 37.5 \\
Convergent Learners & 77 & 37.6 & 86 & 49.7 & 58 & 45.3 \\
Accommodator Learners & 34 & 16.6 & 25 & 14.5 & 12 & 9.4 \\
Total & 205 & 100 & 173 & 100 & 128 & 100 \\
\hline
\end{tabular}

Table 3. The Descriptive for the Pre-service Teachers' Mathematics Teaching Anxiety

\begin{tabular}{llll}
\hline & $N$ & $\bar{X}$ & $S D$ \\
\hline Pre-service Elementary School Teachers & 205 & 45.83 & 13.46 \\
Pre-service Elementary Mathematics Teachers & 173 & 43.39 & 12.28 \\
Pre-service Secondary Mathematics Teachers & 128 & 42.98 & 13.37 \\
Total & 506 & 44.28 & 13.08 \\
\hline
\end{tabular}


Although there were mean score differences between the groups, table 4 demonstrates that the differences between groups were not statistically significant $\left[\mathrm{F}_{(2-503)}\right.$ $=2.469, \mathrm{p}>.05]$. In other words, there was no difference between pre-service elementary and secondary mathematics teachers' teaching anxiety. Likewise, there was no statistically significant difference in mathematics teaching anxiety between pre-service elementary school teachers and pre-service elementary mathematics or preservice secondary mathematics teachers. But results showed that the pre-service teachers' levels of mathematics teaching anxiety decreased from elementary through secondary teachers.

\section{Styles \\ Mathematics Teaching Anxiety and Learning}

Question 3: What differences, if any, exist in mathematics teaching anxiety among the pre-service teachers based on their learning styles?

According to table 5, among all pre-service teachers, the convergent learners had the lowest mean score of teaching mathematics anxiety $(\bar{X}=40.99)$. In contrast, divergent learners had the highest mean score of mathematics teaching anxiety $(\bar{X}=49.88)$. There were mean score differences regarding mathematics teaching anxiety among all groups, as shown in table 6. One-way ANOVA indicated that there was a statistically significant difference among the pre-service teachers based on learning styles $\left[F_{(3-502)}=10.215, \mathrm{p}<.001\right]$.
According to the results of the Tukey multi-comparison test, there was a statistically significant difference in mathematics teaching anxiety between the convergent and the other three types of learners, divergent, assimilator and accommodator [convergent-divergent, $\mathrm{p}=0.000<0.001$; convergent-assimilator, $\mathrm{p}=0.003<0.05$; convergent-accommodator, $\quad \mathrm{p}=0.001<0.05]$. This difference was in favour of convergent learners. On the other hand, there were no differences in teaching anxiety among divergents, assimilators, and accommodators. In short, the study found that the convergent learners had less teaching anxiety in mathematics than the other types of learners.

\section{DISCUSSION AND CONCLUSION}

The first question of the study was to find the preservice elementary school teachers, and pre-service elementary and secondary mathematics teachers' learning styles. This study found that the participants had all four learning styles in different percentages. The convergent learners were in first order, the assimilator learners were in second order, the accommodator learners were in third order, and the divergent learners were in fourth order. This order was not different in pre-service elementary school teachers, or in pre-service elementary or secondary mathematics teachers' learning styles. In each category the convergent learners were in the highest percentage, and the divergent learners were in the lowest percentage. This result agrees with the findings of Peker (2005) and Peker and Mirasyedioğlu

Table 4. One-Way ANOVA Results for the Pre-service Teachers' Mathematics Teaching Anxiety

\begin{tabular}{llllll}
\hline & Sum of Squares & df & Mean Squares & F & p \\
\hline Between Groups & 839.898 & 2 & 419.949 & 2.469 & .086 \\
Within Groups & 85570.918 & 503 & 170.121 & & \\
Total & 86410.816 & 505 & & & \\
\hline
\end{tabular}

Table 5. The Descriptive for Pre-service Teachers' Mathematics Teaching Anxiety by Learning Styles

\begin{tabular}{llll}
\hline & $N$ & $\bar{X}$ & $S D$ \\
\hline Divergent Learners & 51 & 49.88 & 12.59 \\
Assimilator Learners & 163 & 45.59 & 12.18 \\
Convergent Learners & 221 & 40.99 & 12.74 \\
Accommodator Learners & 71 & 47.44 & 14.01 \\
Total & 506 & 44.28 & 13.08 \\
\hline
\end{tabular}

Table 6. One-Way ANOVA Results for the Pre-service Teachers' Mathematics Teaching Anxiety by Learning Styles

\begin{tabular}{llllll}
\hline & Sum of Squares & df & Mean Squares & F & p \\
\hline Between Groups & 4971.602 & 3 & 1657.201 & 10.215 & $.000^{*}$ \\
Within Groups & 81439.215 & 502 & 162.230 & & \\
Total & 86410.816 & 505 & & & \\
\hline
\end{tabular}

${ }^{*} \mathrm{p}<.001$ 
(2008), who found that there appears to be differences in the distribution of learning styles. The percentages of divergent learners and accommodator learners are surprisingly low. Orhun (2007) reported that no students were observed to prefer the accommodator learners among the mathematics students in her university. She also stated that the percentage of convergent learners was numerically higher than other learners among the participants.

The answer to the second question concerned the pre-service teachers' mathematics teaching anxiety. All groups of pre-service teachers had teaching anxieties in mathematics. However, the pre-service elementary school teachers had the highest level of mathematics teaching anxiety and the pre-service secondary mathematics teachers had the lowest level of teaching anxiety in mathematics. Although there were mean score differences with reference to mathematics teaching anxiety between the pre-service elementary school teachers and pre-service elementary and secondary mathematics teachers, these differences were not statistically significant $\left[\mathrm{F}_{(3-502)}=2.469, \mathrm{p}>.05\right]$. Peker (2008) found that when the need of finding concrete examples for pre-service teachers' teaching is increasing, the pre service teachers' level of teaching anxiety in mathematics is also increasing. According to Grouws and Cebulla (2000), the use of concrete materials for a long time, especially in the primary education period, positively increases students' mathematics success and causes students to develop positive attitudes towards mathematics. Therefore, if the elementary mathematics teachers teach mathematics in a concrete way, it may result in students' success and positive attitudes towards mathematics. This circumstance is stressed within the curriculum of mathematics method courses in teacher education programs.

Finally, the study examined the differences in the pre-service teachers' mathematics teaching anxiety according to their learning style preferences. The study indicated that there was a statistically significant difference among the pre-service teachers based on learning styles $\left[\mathrm{F}_{(3-502)}=10.215, \mathrm{p}<.001\right]$. Also, the study showed that the divergent learners $(49.88 \%)$ had the highest level of mathematics teaching anxiety, followed by the accommodator learners (47.44\%). The assimilator learners $(45.55 \%)$ were third, and the convergent learners $(40.99 \%)$ had the lowest level of mathematics teaching anxiety. This finding is consistent with the claim of Peker, Mirasyedioğlu, and Yalın (2003) who stated that the in-service mathematics teachers teach in an appropriate way for those who are assimilator and convergent learners. Likewise, Peker (2005) found that convergent learners were more successful than the other three learner types, and the convergent learners had the lowest anxiety level in mathematics teaching.
The group in which divergent or accommodator learners number the fewest is pre-service secondary mathematics teachers. Pre-service elementary teachers present the topics to students who are in the concrete operational stage among Piaget's cognitive developmental stages. It is thought that pre-service elementary teachers attach more importance to concrete learning since they are educated at universities this way. Moreover, it is evident that pre-service elementary teachers lay more stress on concrete learning compared to pre-service secondary mathematics teachers. However, it is stated that traditional teaching methods commonly followed in general mathematics courses offered in high schools in Turkey are in favour of assimilator and convergent learners (Peker, Mirasyedioğlu, \& Yalın, 2003). Therefore it is expected that the number of assimilator and convergent learners would be higher than the other types.

In short, the study documented that the pre-service elementary school teachers, and pre-service elementary and secondary mathematics teachers, included all types of learning styles: convergent, assimilator, accommodator, and divergent. In the study the percentage of the sum of the convergent and assimilator learners was generally about seventy percent or above. Moreover, the pre-service elementary school teachers had the highest level of mathematics teaching anxiety. On the other hand, the pre-service secondary mathematics teachers showed the lowest level of mathematics teaching anxiety. The study also found that while the divergent learners showed the highest level of mathematics teaching anxiety, the convergent learners showed the lowest level of mathematics teaching anxiety.

Sloan, Daane, and Giesen (2002) reported that there were many variables affecting mathematics anxiety, such as learning styles, instructional methods, mathematics achievement levels, and confidence in doing mathematics. This study indicated that learning style preference may affect the pre-service teachers' mathematics teaching anxiety. There can be several reasons for mathematics teaching anxiety for a preservice teacher or even an in-service teacher. For instance, anxiety may arise because the teaching point is difficult, or the mathematical knowledge of the pre- or in-service teacher may be inadequate. Moreover, pre- or in-service teachers' level of interest towards the teaching profession may be inadequate. It may be because of preor in-service teachers' inability to teach in a way that is appropriate to the level of the developmental stage of the learners. Investigation of these variables as they relate to mathematics teaching anxiety might be conducted in future studies. 


\section{RECOMMENDATIONS AND FUTURE RESEARCH}

The major aim of the teacher education programs is to provide every pre-service teacher with the best level of teaching. However, in a real classroom there is not just one learner type. It should be taken into account that there are pre-service teachers that may prefer a different learning style. If the teacher educators teach by taking only one group's learning characteristics into account, then they help only that group be successful and establish a positive attitude towards mathematics. In this sense, those teacher educators are not able to meet the other type of learners' needs. The teacher educators who recognize that pre-service teachers differ in learning style preferences might be taking the first step in reducing the mathematics teaching anxiety of preservice teachers. In this study, it is estimated that mathematics educators also have a role in the difference in pre-service teachers' mathematics teaching anxiety levels that is due to learning styles. It can be expected that all these different learning styles will lose their effect on success if mathematics is taught by taking every pre-service teacher's learning characteristics into account. As pre-service teachers' mathematics teaching anxiety levels decrease, the differences among preservice teachers according to different variables may disappear, because the main purpose is to make sure that every pre-service teacher learns at an optimum and equal level together with others. Like many other researchers (Morris \& McCarthy, 1990; Harb, Durrant, \& Terry, 1993; Knisley, 2002; Peker \& Mirasyedioğlu, 2008) I hope that the learning cycle (or 4 MAT system) constructed according to different learning styles will improve mathematics achievement and attitudes towards mathematics teaching among pre-service teachers. Pre-service teachers can find that all the features of the four learner types, and the difference between their mathematics teaching anxieties depending on learning styles, can be eliminated by applying the 4 MAT system. Then there will be a learning system covering all the learning styles. The main responsibility belongs to the teacher educators. They should know that learning style affects success, attitudes, mathematics success, and mathematics teaching anxiety.

The findings of this study encourage the others, such as mathematicians, educators, and researchers to evaluate the effects of learning styles in teacher education.

\section{REFERENCES}

Aksu, M. \& Saygi, M. (1988). The effects of feedback treatment on math-anxiety levels of sixth grade Turkish students. School Science and Mathematics, 88, 390-396.
Altermatt, E.R. \& Kim, M.E. (2004). Can anxiety explain sex differences in college entrance exam scores? Journal of College Admission, 183, 6-11.

Ameen, E.C., Guffey, D.M., \& Jackson, C. (2002). Evidence of teaching anxiety among accounting educators. Journal of Education for Business, 78(1), 16-22.

Askar, P., \& Akkoyunlu, B. (1993). Kolb öğrenme sitili envanteri. Eğitim ve Bilim. 87, 37-47.

Austin, S., Wadlington, E., \& Bitner, J. (1992). Effect of beliefs about mathematics on math anxiety and math self-concept in elementary teachers. Education, 112(3), 390-396.

Baker, R., Dixon, N., \& Kolb, D.A. (1985). Personal learning guide. Boston: McBer and Company.

Baloğlu, M. (1999). A comparison of mathematics anxiety and statistics anxiety in relation to general anxiety, Eric Document Reproduction Service No. ED436703.

Baloğlu, M. (2001). Matematik korkusunu yenmek. Kuram ve Uygulamada Eğitim Bilimleri Dergisi, 1(1), 59-76.

Baloğlu, M. (2005). Adaptation of the Mathematics Anxiety Rating Scale to Turkish, language validity and preliminary psychometric properties. Kuram ve Uygulamada Eğitim Bilimleri Dergisi, 5(1), 23-30.

Beasley, T.M., Long, J.D., \& Natali, M. (2001). A confirmatory factor analysis of the mathematics anxiety scale for children. Measurement and Evaluation in Counselling and Development, 34, 14-26.

Brady, P. \& Bowd, A. (2005). Mathematics anxiety, prior experience and confidence to teach mathematics among pre-service education students. Teachers and Teaching: Theory and Practice, 11(1), 37-46.

Brown, T., McNamara, O., Hanley, U., \& Jones, L. (1999). Primary student teachers' understanding of mathematics and its teaching. British Educational Research Journal, 25(3), 299-322.

Cassady, J.C. \& Johnson, R.E. (2002). Cognitive test anxiety and academic performance. Contemporary Educational Psychology, 27(2), 270-295.

Dunn, R., Beaudry, J.S., \& Klavas, A. (1989). Survey of research on learning styles. Educational Leadership, 46(6), 50-58.

Engelhard, G. (1990). Math anxiety, mother's education, and the mathematics performance of adolescent boys and girls: evidence from the United States and Thailand. The Journal of Psychology, 124(3), 289-298.

Fish, T.A. \& Fraser, I.H. (2001). Exposing the iceberg of teaching anxiety: a survey of faculty at three New Brunswick Universities. Electronic Journal of the American Association of Behavioral and Social Sciences, 4, Available at http://www.aabss.org/journal2001/Fish2001.jmm.html , Retrieved 8 April 2008 (last accessed 8 April 2008).

Gardner, L. \& Leak, G. (1994). Characteristics and correlates of teaching anxiety among college psychology teachers. Teaching of Psychology, 21(1), 28-32.

Gasiorowski, J.H. (1998). The relationship between student characteristics and math achievement when using computer spreadsheets, Doctoral Dissertation, West Virginia University.

Godbey, C. (1997). Mathematics anxiety and the under prepared student, ERIC Document Reproduction Service No. ED 426734. 
Gresham, G. (2007). A study of mathematics anxiety in preservice teachers. Early Childhood Education Journal, 35(2), 181-188.

Grouws, D.A. \& Cebulla, K.J. (2000). Improving student achievement in mathematics, part 1: Research findings, ERIC Clearinghouse for Science Mathematics and Environmental Education Columbus OH, ERIC Document Reproduction Service No. ED463952.

Hadfield, O.D. \& Maddux, C. D. (1988). Cognitive style and mathematics anxiety among high school students. Psychology in the Schools, 25(1), 75-83.

Hadfield, O.D., Martin, J.V., \& Wooden, S. (1992). Mathematics anxiety and Learning style of Navajo middle school student. School Science and Mathematics, 92(4), 171-176.

Halat, E. (2006). Sex-related differences in the acquisition of the van Hiele levels and motivation in learning geometry. Asia Pacific Education Review, 7(2), 173-183.

Halat, E. (2007). Reform-based curriculum \& acquisition of the level. Eurasia Journal of Mathematics, Science and Technology Education, 3(1), 41-49.

Harb, J.N., Durrant, S.O., \& Terry, R.E. (1993). Use of the Kolb learning cycle and the 4 MAT system in engineering education. Journal of Engineering Education, 82(2), 70-77.

Hembree, R. (1990). The nature, effect, and relief of mathematics anxiety. Journal for Research in Mathematics Education, 21(1), 33-46.

Idris, N. (2006). Exploring the effects of TI-84 plus on achievement and anxiety in mathematics. Eurasia Journal of Mathematics, Science and Technology Education, 2(3), 66-78.

Iossi, L. (2007). Strategies for reducing math anxiety in post-secondary students. In S. M. Nielsen, M. S. Plakhotnik (Eds.), Proceedings of the Sixth Annual College of Education Research Conference: Urban and International Education Section (pp. 30-35). Miami, USA: Florida International University.

Knisley, J. (2002). A four-stage model of mathematical learning. Mathematics Educator, 12(1), 11-16.

Kolb, D.A. (1976). Learning style inventory: Technical Manual. Boston: McBer and Company.

Kolb, D.A. (1984). Experiential learning: experience as the source of learning and development. New Jersey: Prentice Hall, Inc.

Kolb, D.A. (1985). Learning style inventory: Self scoring inventory and interpretation booklet. Boston: McBer and Company.

Levine, G. (1993). Prior mathematics history, anticipated mathematics teaching style, and anxiety for teaching mathematics among preservice elementary school teachers. Paper presented at the Annual Meeting of the International Group for Psychology of Mathematics Education, North American Chapter, ERIC Document Reproduction Service No. ED373972.

Levine, G. (1996). Variability in anxiety for teaching mathematics among pre-service elementary school teachers enrolled in a mathematics course, Paper presented at the Annual Meeting of the American Educational Research Association in New York, ERIC Document Reproduction Service No. ED398067.

Malinsky, M., Ross, A., Pannells, T., McJunkin, M. (2006). Math Anxiety in pre-service elementary school teachers. Education, 127(2), 274-279.
Morris, S. \& McCarthy, B. (1990). 4 MAT in action II: Sample lesson plans for use with the 4 MAT system. Barrington: Excel, Inc.

National Council of Teachers of Mathematics (NCTM). (1989). Curriculum and evaluation standards for school mathematics, Reston, VA.

Newstead, K. (1988). Aspect of children's mathematics anxiety. Educational Studies in Mathematics, 36, 53-71.

Orhun, N. (2007). An investigation into the mathematics achievement and attitude towards mathematics with respect to learning style according to gender. International Journal of Mathematical Education in Science and Technology, 38(3), 321-333.

Peker, M. (2005). İlköğretim matematik öğretmenliğini kazanan öğrencilerin öğrenme stilleri ve matematik başarısı arasındaki ilişki Eğ̈tim Araștırmalar Dergisi, 21, 200-210.

Peker, M. (2006). Matematik öğretmeye yönelik kayg1 ölçeğinin geliştirilmesi. Eğitim Bilimleri ve Uygulama, 9, 7392.

Peker, M. (2008). Eğitim programlar ve ögretmen adaylarmm matematik ögretme kaygısı. VIII. Ulusal Fen Bilimleri ve Matematik Eğitimi Kongresi'nde sunulmuş bildiri.

Peker, M. \& Halat, E. (2008). The pre-service teachers' mathematics teaching anxiety and gender. Paper presented in The European Conference on Educational Research (12 September, Gothenburg, Sweden).

Peker, M. \& Mirasyedioğlu, Ş. (2008). Pre-service elementary school teachers' learning styles and attitudes towards mathematics. Eurasian Journal of Mathematics, Science \& Technology Education, 4(1), 21-26.

Peker, M., Mirasyedioğlu, Ş., \& Yalın, H.İ. (2003). Öğrenme stillerine dayalı matematik öğretimi. Türk Ĕ̈itim Bilimleri Dergisi, 1(4), 371-384.

Sloan, T., Daane, C.J., \& Giesen, J. (2002). Mathematics anxiety and learning styles: What is the relationship in elementary preservice teachers? School Science and Mathematics, 102(2), 84-87.

Sloan, T.R., Vinson, B., Haynes, J., \& Gresham, R. (1997). A comparison of pre-and post-levels of mathematics anxiety among preservice teacher candidates enrolled in a mathematics methods course. Paper presented at the Annual Meeting of Midsouth Educational Research Association in Nashville, ERIC Document Reproduction Service No. ED417137.

Smith, R.R. (1996). Effects of textbook, static CAI, and animated $C A I$, and learning styles on achievement of college students in symbolic matrix algebra, Doctoral Dissertation, University of South Florida.

Tooke, D. J. \& Lindstrom, L.C. (1998). Effectiveness of a mathematics methods course in reducing math anxiety of preservice elementary teachers. School Science and Mathematics, 98(3), 136-139.

Trujillo, K.M. \& Hadfield, O.D. (1999). Tracing the roots of mathematics anxiety through in-depth interviews with preservice elementary teachers. College Student Journal, 33(2), 219-232.

Uusimaki, L. \& Nason, R. (2004). Causes underlying pre-service teachers' negative beliefs and anxieties about mathematics. Proceedings of the 28th Conference of the International Group for the Psychology of Mathematics Education, 4, 369-376. 
Vinson, B.M. (2001). A comparison of preservice teachers' mathematics anxiety before and after a methods class emphasizing manipulatives. Early Childhood Education Journal, 29(2), 89-94.

Vinson, B.M., Haynes, J., Brasher, J., Sloan, T., \& Gresham, T. (1997). A comparison of preservice teachers' mathematics anxiety before and after a methods class emphasizing manipulatives, ERIC Document Reproduction Service No. ED 417136.

Wigfield, A. \& Meece, J. (1988). Math anxiety in elementary and secondary school students. Journal of Educational Psychology, 80, 210-216.

\section{$\diamond \diamond \diamond$}

